University of Nebraska - Lincoln

DigitalCommons@University of Nebraska - Lincoln

Early weaning in Northern Great Plains beef cattle production systems: II. Development of replacement heifers weaned at 80 or $215 \mathrm{~d}$ of age

\author{
R.C. Waterman \\ USDA-ARS, richard.waterman@ars.usda.gov \\ T.W. Geary \\ USDA-ARS \\ J.A. Paterson \\ Montana State University \\ R.J. Lipsey \\ American Simmental Association
}

Follow this and additional works at: https://digitalcommons.unl.edu/usdaarsfacpub

Waterman, R.C.; Geary, T.W.; Paterson, J.A.; and Lipsey, R.J., "Early weaning in Northern Great Plains beef cattle production systems: II. Development of replacement heifers weaned at 80 or $215 \mathrm{~d}$ of age" (2012). Publications from USDA-ARS / UNL Faculty. 1176.

https://digitalcommons.unl.edu/usdaarsfacpub/1176

This Article is brought to you for free and open access by the U.S. Department of Agriculture: Agricultural Research Service, Lincoln, Nebraska at DigitalCommons@University of Nebraska - Lincoln. It has been accepted for inclusion in Publications from USDA-ARS / UNL Faculty by an authorized administrator of DigitalCommons@University of Nebraska - Lincoln. 


\title{
Early weaning in Northern Great Plains beef cattle production systems: II. Development of replacement heifers weaned at 80 or $215 \mathrm{~d}$ of age
}

\author{
R.C. Waterman ${ }^{\text {a,* }}$, T.W. Geary ${ }^{\text {a }}$, J.A. Paterson ${ }^{\text {b }}$, R.J. Lipsey ${ }^{c}$ \\ a USDA-ARS, Fort Keogh Livestock and Range Research Laboratory, 243 Fort Keogh Road, Miles City, MT 59301-4016, USA \\ ${ }^{\mathrm{b}}$ Department of Animal and Range Sciences, Montana State University, Bozeman, MT 59717, USA

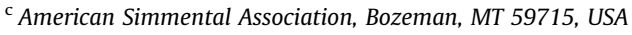

\section{A R T I C L E I N F O}

\section{Article history:}

Received 2 December 2011

Received in revised form

26 April 2012

Accepted 29 April 2012

\section{Keywords:}

Beef heifer

Early weaning

Reproduction

Serum metabolites

\begin{abstract}
A B S T R A C T
Studies were conducted to evaluate effects of weaning and subsequent heifer development treatments within two herds located in the Northern Great Plains, USA. Heifer calves from predominantly Angus $\times$ Hereford dams were stratified within dam age and calving date (Fort Keogh Livestock and Range Research Laboratory (LARRL), Miles City, MT, USA; $n=328$ ) and randomly assigned within study and strata to one of three weaning treatments. Heifer calves from Angus and Angus $\times$ Simmental dams ( $n=167$; Judith Gap (JG), MT, USA) were stratified within breed group by age, calving date, and AI sire. Heifer calves either remained with their dams until time of normal weaning (NW; approximately $213 \mathrm{~d}$ of age) or were early weaned (approximately $80 \mathrm{~d}$ of age) onto one of two early weaning (EW) diets. Heifer calves assigned to EW treatments received one of the following diets: (1) $17.5 \% \mathrm{CP}$ (69\% RDP and $7.53 \mathrm{MJ} / \mathrm{kg} \mathrm{NEm}$ or (2) $17.5 \% \mathrm{CP}$ (57\% RDP and $7.69 \mathrm{MJ} / \mathrm{kg} \mathrm{NEm}$ ). At the time of normal weaning, heifers from LARRL (2005 and 2006) were further divided into two heifer development (HD) diet treatments that differed only in proportion of RDP: (1) $12.5 \% \mathrm{CP}$ (83\% RDP and $6.28 \mathrm{MJ} / \mathrm{kg} \mathrm{NEm}$ ); or (2) $12.5 \% \mathrm{CP}$ (72\% RDP and $6.28 \mathrm{MJ} / \mathrm{kg} \mathrm{NEm}$ ). Heifers from JG were fed a common heifer development diet. Heifer BW at time of normal weaning revealed that EW heifers were heavier, regardless of type of protein delivered by EW treatments $(P<0.10)$. Heifer BW at the end of the development period was greater for EW heifers at LARRL $(P<0.01)$ and similar for JG heifers $(P=0.35)$ regardless of weaning treatment. Heifers at LARRL that received EW treatments had a greater percentage pubertal $(P<0.06)$ from 39 to $2 \mathrm{~d}$ before breeding compared to NW heifers. Pregnancy rates were not influenced by early weaning or heifer development treatments at LARRL $(P>0.05)$; however, a greater percentage of EW heifers became pregnant throughout the breeding season at JG $(P=0.03)$. These experiments demonstrate early weaning is a viable option to develop and breed heifers in extensive beef production systems in the Northern Great Plains, USA. When production may be jeopardized by environmental conditions (e.g., drought), early weaning calves will not impair a heifers opportunity to be retained as replacement females as early weaned heifers have similar or greater reproductive success than heifers that are normal weaned.
\end{abstract}

Published by Elsevier B.V.

USDA, Agricultural Research Service, Northern Plains Area, is an equal opportunity/affirmative action employer. All agency services are available without discrimination. This research was conducted under a cooperative agreement between USDA-ARS and the Montana Agricultural Experiment Station. Mention of a proprietary product does not constitute a guarantee or warranty of the product by USDA, Montana Agricultural Experiment Station, or the authors and does not imply its approval to the exclusion of other products that also may be suitable.

* Corresponding author. Tel.: +1 406874 8208; fax: +1 4068748289.

E-mail address: richard.waterman@ars.usda.gov (R.C. Waterman). 


\section{Introduction}

Sustainability of extensive beef production enterprises utilizing within enterprise development of replacement females are economically dependent on the reproductive success of these females. A successfully planned development strategy for replacement heifers is crucial in order to obtain timely puberty (Arije and Wiltbank, 1971; Short and Bellows, 1971; Wiltbank et al., 1966), promote lifetime productivity and optimize milking ability (Pinney et al., 1972; Swanson, 1960). Grings et al. (2007) concluded that heifers, when weaned at 140,190 , or $240 \mathrm{~d}$ of age, and subsequently developed on either constant or delayed gain management strategies can all achieve similar reproductive success. Furthermore, spring-born heifers, of similar age, weaned on fall pasture then subjected to a period of dry lot confinement had similar attainment of puberty as heifers consuming a corn silage based diet throughout the same time period in the Northern Great Plains, USA (Grings et al., 1998). Clanton et al. (1983) concluded that producers have many options to effectively develop replacement heifers as long as necessary body weight (BW; industry standard of $65 \%$ of mature BW) that supports reproductive competency is achieved by the start of breeding. Therefore, the objectives of this study were to evaluate, growth and reproductive performance in heifer calves weaned at a younger age (approx. 80-d postpartum) and provided dietary protein differing in proportions of ruminally degradable (RDP) and undegradable protein (RUP) compared to heifers managed with their dams until a more traditional weaning age (approx. 215-d postpartum).

\section{Material and methods}

\subsection{Study areas}

The study was conducted in two locations in the Northern Great Plains. One site was located approximately $5 \mathrm{~km}$ northeast of Judith Gap (JG), MT $\left(46^{\circ} 41^{\prime} \mathrm{N}\right.$, $\left.109^{\circ} 45^{\prime} \mathrm{W}\right)$, USA at an average elevation of $1270 \mathrm{~m}$. The second site was the USDA-ARS, Fort Keogh Livestock and Range Research Laboratory (LARRL) located approximately $1.6 \mathrm{~km}$ west of Miles City, MT (46 $\left.22^{\prime} \mathrm{N}, 105^{\circ} 5^{\prime} \mathrm{W}\right)$, USA at an average elevation of $730 \mathrm{~m}$. Additional descriptions of each site are described in Waterman et al. (in press.).

\subsection{Animals, measurements and management}

\subsubsection{Early weaning}

The LARRL Institutional Animal Care and Use Committee approved all animal handling procedures used in the present experiments.

Heifer calves at the JG location (2005) were from Angus and Angus $\times$ Simmental dams. Heifer calves were stratified within breed group by dam age, calving date, and AI sire (when applicable). Heifer calves at LARRL (2005 and 2006) were from crossbred dams (predominantly Angus $\times$ Hereford) and stratified within dam age and calving date. All heifer calves from JG and LARRL were randomly assigned within location and strata to one of three weaning treatments at approximately $80 \mathrm{~d}$ of age. Heifer calves $(n=167$ and $78.9 \pm 1.35 \mathrm{~d}$ of age, 164 and $82.0 \pm 1.58 \mathrm{~d}$ of age, and $16483.9 \pm 1.20 \mathrm{~d}$ of age for JG in 2005 and LARRL in 2005 and 2006, respectively) either remained with their dams until normal weaning (NW) or were weaned at a younger age into one of two early weaning (EW) diet treatments. Early weaning diet treatments differed only in amounts of RDP (Table 1) provided in their diets. Heifer calves assigned to EW treatments received one of the following diets: (1) 33:67 forage: concentrate diet containing $17.5 \%$ crude protein (CP; $69 \%$ $\mathrm{RDP}$ ) and $3.43 \mathrm{MJ} / \mathrm{kg}$ net energy for maintenance (NEm; EW-69; $n=162$ ); or (2) 33:67 forage: concentrate diet containing $17.5 \% \mathrm{CP}$ (57\% RDP) and $3.51 \mathrm{MJ} / \mathrm{kg} \mathrm{NEm} \mathrm{(EW-}$ $57 ; n=162$ ). Heifer calves were allocated to 2 pens (JG approx. 27/pen) or 3 pens (LARRL approx. 18/pen) within each EW diet treatment, with diets fed ad libitum and adjusted daily by previous day's intake. Heifer BW was

Table 1

Ingredients and nutrient composition of diets fed to early weaned heifer calves.

\begin{tabular}{|c|c|c|}
\hline \multirow[b]{2}{*}{ Item $^{\mathrm{a}}$} & \multicolumn{2}{|l|}{ Diet $^{b}$} \\
\hline & EW-69 & EW-57 \\
\hline Ingredient & \multicolumn{2}{|c|}{$\%$ of DM } \\
\hline Barley hay & 32.64 & 32.525 \\
\hline Soybean hulls & 14.558 & 20.338 \\
\hline Corn, ground & 16.728 & 20.06 \\
\hline Dried distillers grains & 10.545 & 14.712 \\
\hline Canola meal 34\% & 12.048 & 0.666 \\
\hline Wheat middlings & 8.872 & 2.505 \\
\hline Hydrolyzed feather meal & - & 4.016 \\
\hline Molasses, cane & 3.346 & 3.34 \\
\hline Dicalcium phosphate & 0.249 & 0.994 \\
\hline Selenium (selenite) & 0.348 & 0.248 \\
\hline Potassium chloride & 0.03 & 0.209 \\
\hline Calcium carbonate & 0.498 & 0.149 \\
\hline Trace mineral premix ${ }^{c}$ & 0.07 & 0.07 \\
\hline Aureo $198 \mathrm{~g} / \mathrm{kg}^{\mathrm{d}}$ & 0.06 & 0.06 \\
\hline Zinc sulfate & 0.007 & 0.007 \\
\hline Vitamin premix ${ }^{\mathrm{e}}$ & 0.001 & 0.001 \\
\hline Nutrient composition ${ }^{f}$ & \multicolumn{2}{|c|}{$\mathrm{MJ} / \mathrm{kg}$} \\
\hline NEm & 7.53 & 7.69 \\
\hline $\mathrm{NEg}$ & 4.90 & 5.06 \\
\hline & \multicolumn{2}{|c|}{$\%$} \\
\hline DM & 87.6 & 87.8 \\
\hline TDN & 75.3 & 75.1 \\
\hline $\mathrm{CP}$ & 17.5 & 17.5 \\
\hline $\mathrm{RDP}(\%$ of $\mathrm{CP})$ & 68.7 & 57.3 \\
\hline RUP (\% of CP) & 31.3 & 42.7 \\
\hline
\end{tabular}

a Net energy maintenance (NEm); net energy gain (NEg); dry matter (DM); total digestible nutrients (TDN); crude protein (CP); ruminally degradable protein (RDP), ruminally undegradable protein (RUP).

b Diets formulated on a DM basis to be isocaloric and isonitrogenous; Early weaning (EW); EW-69 (69\% RDP) and EW-57 (57\% RDP).

${ }^{\mathrm{c}}$ Contains $7.82 \% \mathrm{Ca}$ and supplied the following amounts $/ \mathrm{kg}$ in premix: $2000 \mathrm{mg}$ Co; $120,000 \mathrm{mg} \mathrm{Cu} ; 10,600 \mathrm{mg} \mathrm{I}$; 35,000 mg Fe; $170,000 \mathrm{mg} \mathrm{Mg}$; and 400,000 $\mathrm{mg} \mathrm{Zn}$.

d Contained $198 \mathrm{~g}$ chlortetracycline/kg (Alpharma Inc., Fort Lee, NJ 07024, USA).

e Contains the following amounts/kg in premix: 180,000 KIU, Vitamin A; 18,000 KIU, Vitamin D; and 353,000 IU, Vitamin E.

${ }^{\mathrm{f}}$ Based on analyzed chemical composition of individual ingredients. 
measured once and recorded at time of early weaning (JG May 9, 2005, LARRL July 5, 2005, and LARRL July 10, 2006: d 0, respectively) and normal weaning (JG September 19, 2005, LARRL November 15, 2005, and LARRL November 20, 2006; d 133, respectively). Blood samples were collected from calves via jugular or coccygeal venipuncture (Corvac, Sherwood Medical, St. Louis, MO, 63103 USA) on d 0 and 133 before feeding for future analysis of blood metabolites.

Blood samples were allowed to coagulate overnight at $4{ }^{\circ} \mathrm{C}$, and centrifuged at $1500 \times \mathrm{g}$ for $30 \mathrm{~min}$. Serum was decanted and stored at $-20{ }^{\circ} \mathrm{C}$ until analysis. Serum metabolite concentrations were analyzed in duplicate using commercially available kits. Glucose was measured via the glucose oxidase method (Kit TR15321; Thermo DMA, Louisville, CO, 80027 USA; with $4.3 \%$ intraassay CV and $7.9 \%$ interassay $\mathrm{CV}$ ), urea-N via the urease method (Kit TR12321; Thermo DMA, Louisville, CO, 80027 USA; with $3.4 \%$ intraassay $\mathrm{CV}$ and $5.5 \%$ interassay $\mathrm{CV}$ ), and NEFA via the ACS-ACOD method (Cat. no. 994-75409; Wako Chemicals USA, Inc., Richmond, VA, 23223 USA; with $5.5 \%$ intraassay CV and $7.6 \%$ interassay CV). Serum insulin concentrations were measured in duplicate using solidphase ${ }^{125}$ I-insulin RIA (Coat-a Count kit, Diagnostic Products Inc., Los Angeles, CA, 90045 USA). The insulin assay had $3.5 \%$ intraassay and $9.1 \%$ interassay CV with $102 \%$ recovery.

\subsubsection{Heifer development}

Two experiments were conducted to investigate heifer development in this study. In experiment 1 , heifers at LARRL were stratified by previous weaning treatment (EW-69, EW-57, and NW) into two heifer development (HD) diet treatments $27 \mathrm{~d}$ (2005) and $8 \mathrm{~d}$ (2006) after normal weaning that differed only in proportion of RDP; (1) $12.5 \% \mathrm{CP}$ [83\% RDP and $6.28 \mathrm{MJ} / \mathrm{kg} \mathrm{NEm}$ (HD-83; $n=81)]$ or (2) $12.5 \% \mathrm{CP}$ [72\% RDP and $6.28 \mathrm{MJ} / \mathrm{kg} \mathrm{NEm}$ (HD-72; $n=82$ ); Table 2]. Heifers were allotted to 3 pens (approx. 27/pen) within each diet treatment, fed ad libitum and feed adjusted daily by previous day's intake. Heifer BW was measured once and recorded at the initiation (December 12, 2005 and November 28, 2006, respectively) and termination of a $135 \mathrm{~d}$ (April 6, 2006) and $141 \mathrm{~d}$ (April 18, 2007) developmental period.

Blood samples were collected via coccygeal venipuncture at 9- to 11-d intervals beginning approximately 11.5 months (345 d) of age and ending approximately 14 months ( $420 \mathrm{~d}$ ) of age. Serum concentrations of progesterone were used as an indicator of pubertal status (i.e. luteal activity). Concentrations of progesterone in serum samples were determined directly without extraction by solidphase RIA (Coat-a-Count kit; Diagnostic Products Corp., Los Angeles, CA, 90045 USA) as reported previously (Bellows et al., 1991). Intra- and interassay CV were $6.87 \%$ and $2.03 \%$, respectively, and assay sensitivity was $0.08 \mathrm{ng} / \mathrm{mL}$. Pubertal status was defined as the first week that serum progesterone concentration exceeded $1.0 \mathrm{ng} /$ $\mathrm{mL}$. Serum samples collected in the last $30 \mathrm{~d}$ of the development period in each year were composited by heifer for determination of blood metabolite concentrations (glucose, insulin, NEFA, and urea N). Interpretation of
Table 2

Ingredients and nutrient composition of diets fed during heifer development at Fort Keogh Livestock and Range Research Laboratory (LARRL), Miles City, MT, USA in 2005 and 2006.

\begin{tabular}{|c|c|c|}
\hline \multirow[b]{2}{*}{ Item $^{\mathrm{a}}$} & \multicolumn{2}{|l|}{$\operatorname{Diet}^{\mathrm{b}}$} \\
\hline & HD-83 & HD-72 \\
\hline Ingredient & \multicolumn{2}{|c|}{$\%$ of DM } \\
\hline Corn silage & 46.474 & 45.348 \\
\hline Barley hay & 36.959 & 38.619 \\
\hline Barley grain & 10.418 & 10.142 \\
\hline Soybean meal & 3.105 & 1.073 \\
\hline Feather meal & - & 2.341 \\
\hline Urea & 0.801 & 0.39 \\
\hline Ca carbonate & 1.502 & 1.463 \\
\hline Na chloride & 0.601 & 0.488 \\
\hline Vitamin $\mathrm{ADE}^{\mathrm{c}}$ & 0.07 & 0.068 \\
\hline Trace mineral $^{\mathrm{d}}$ & 0.07 & 0.068 \\
\hline Nutrient composition ${ }^{\mathrm{e}}$ & \multicolumn{2}{|c|}{$\mathrm{MJ} / \mathrm{kg}$} \\
\hline NEm & 6.28 & 6.28 \\
\hline \multirow[t]{2}{*}{$\mathrm{NEg}$} & 3.77 & 3.89 \\
\hline & \multicolumn{2}{|c|}{$\%$} \\
\hline DM & 61.9 & 61.8 \\
\hline TDN & 63.1 & 62.6 \\
\hline $\mathrm{CP}$ & 12.5 & 12.5 \\
\hline RDP (\% of CP) & 82.6 & 71.9 \\
\hline RUP (\% of CP) & 17.4 & 28.1 \\
\hline
\end{tabular}

a Net energy maintenance (NEm); net energy gain (NEg); dry matter (DM); total digestible nutrients (TDN); crude protein (CP); ruminally degradable protein (RDP), ruminally undegradable protein (RUP).

${ }^{\mathrm{b}}$ Diets formulated on a DM basis to be isocaloric and isonitrogenous; heifer development (HD); HD-83 (83\% RDP) and HD-72 (72\% RDP).

c Contains 44,000,000 IU/kg vitamin A, 880,000 IU/kg vitamin D, and $880 \mathrm{IU} / \mathrm{kg}$ vitamin $\mathrm{E}$.

d Contains $20.0 \% \mathrm{Mg}, 0.2 \% \mathrm{~K}, 2.6 \% \mathrm{~S}, 18,000 \mathrm{ppm} \mathrm{Cu}, 60,000 \mathrm{ppm} \mathrm{Zn}$ $40,000 \mathrm{ppm} \mathrm{Fe}, 300 \mathrm{ppm} \mathrm{Se}, 60,000 \mathrm{ppm} \mathrm{Mn}, 180 \mathrm{ppm} \mathrm{Co}$, and 1140 ppm I.

e Based on analyzed chemical composition of individual ingredients.

serum metabolite concentrations in response to treatment application was used to provide insight explaining nutritional factors affecting variability in BW and reproductive measures.

Heifers received a single injection of $\mathrm{PGF}_{2 \alpha}(25 \mathrm{mg}$ i.m.; ProstaMate, Teva Animal Health, Saint Joseph, MO, 64507 USA) on d 7 (May 29, 2006 and May 29, 2007) of an 11-d AI breeding period during which only heifers detected in estrus were inseminated. Ovaries of all heifers receiving AI were examined by transrectal ultrasonography using an Aloka 500V ultrasound with a $7.5 \mathrm{MHz}$ linear probe (Aloka, Wallingford, CT, USA) to characterize follicle size at insemination $\sim 12 \mathrm{~h}$ after onset of estrus. In brief, all follicles $\geq 8 \mathrm{~mm}$ in diameter were recorded. Follicle size was determined by averaging follicular diameter at the widest point and perpendicular to the first measurement using the internal calipers on the Aloka 500V (Perry et al., 2007). After AI, heifers were comingled in a single pasture and exposed to bulls $10-14 \mathrm{~d}$ after AI for a 50-d breeding season. Heifers were evaluated for pregnancy by transrectal ultrasonography using a 5-MHz transducer (Aloka, Wallingford, CT, USA) on July 17, 2006 and August 22, 2006, or August 20, 2007. Date of AI and age of fetus at 
pregnancy diagnosis were used to calculate AI and breeding season pregnancy rates.

In experiment 2, heifer calves located at JG (2005), were brought into a single lot for the duration of the development period which began $18 \mathrm{~d}$ after normal weaning. Heifers were fed ad-libitum a total mixed ration which included $14.1 \%$ rolled barley, $32.3 \%$ barley grain hay, $10.6 \%$ triticale silage, $9.8 \%$ wheat straw, $7.9 \%$ wheat middling meal and $1 \%$ growers supplement. The amount fed each day was adjusted according to previous day's intake. Diet nutrient composition was $75.7 \%$ dry matter (DM), 67.5\% total digestible nutrients (TDN), 11.6\% CP (31\% $\mathrm{RDP}$, as a percent of $\mathrm{CP}$ ), $7.28 \mathrm{MJ} / \mathrm{kg} \mathrm{NEm}$, and $3.93 \mathrm{MJ} / \mathrm{kg}$ for net energy of gain (NEg). A single BW measure was recorded at the initiation (October 27, 2005) and the conclusion (April 26, 2006) of the 181-d developmental period.

Heifers at JG were subjected to a 33-d melengestrol acetate (MGA)-PGF $2 \alpha$ treatment $[0.5 \mathrm{mg}$ of MGA/d for $14 \mathrm{~d}$ followed by $\mathrm{PGF}_{2 \alpha}$ (25 mg i.m.) $19 \mathrm{~d}$ after discontinuing MGA feeding] for synchronization of estrus at the end of the development period. Heifers were observed for estrus during daylight hours of the 5-d period after $\mathrm{PGF}_{2 \alpha}$ (April $23,2006)$ and artificially inseminated approximately $12 \mathrm{~h}$ after onset of estrus. After AI, heifers were relocated to a single pasture and exposed to bulls 10-14 d after AI for the remainder of a 50-d breeding season. Heifers were evaluated for pregnancy by transrectal ultrasonography using a 5-MHz transducer (Aloka, Wallingford, CT, USA) on August 8, 2006. Date of AI and age of fetus at pregnancy diagnosis were used to calculate AI and breeding season pregnancy rates.

\subsection{Statistical analysis}

\subsubsection{Early weaning}

Heifer weaning treatment performance and metabolite data were analyzed using the MIXED procedure in SAS (SAS Inst. Inc., Cary, NC, USA) with a model that included weaning treatment (NW, EW-69, and EW-57) with pen (JG) or pen within year (LARRL) included in the RANDOM statement. Covariates used included average daily gain (ADG) from birth to time of early weaning. Two preplanned single degree of freedom estimates were constructed to separate least squares means due to weaning treatment: (1) NW vs. EW to evaluate dietary influences between weaning treatments; and (2) EW-69 vs. EW-57 to evaluate early weaning diets differing in the proportions of RDP. Tukey-Kramer adjusted least squares means was computed and a significance level was set at $P \leq 0.05$.

\subsubsection{Heifer development}

Heifer performance, metabolite data, and dominant ovulatory follicle size at time of AI for the development period were analyzed for LARRL heifers using the MIXED procedure in SAS (SAS Inst. Inc., Cary, NC) with a model that included weaning treatment (NW, EW-69, and EW57) and heifer development treatment (HD-83 and HD-72) along with their interaction. The RANDOM statement of SAS was used and included pen within year. Covariates used included ADG from parturition to time of EW. Two preplanned single degree of freedom estimates were constructed to separate least squares means due to weaning treatment: (1) NW vs. EW to evaluate dietary influences between weaning treatments; and (2) EW-69 vs. EW-57 to evaluate early weaning diets differing only in the proportions of RDP. Tukey-Kramer adjusted least squares means was computed and a significance level was set at $P \leq 0.05$. No weaning treatment $\times$ heifer development treatment was observed $P>0.19$ therefore, only main effects are presented.

Estrous response, AI conception rate, and pregnancy rate for LARRL heifers was evaluated using PROC LOGISTIC (SAS Inst. Inc., Cary, NC) with a model that included weaning treatment (NW, EW-69, and EW-57), heifer development treatment (HD-83 and HD-72) along with their interaction. Tukey-Kramer adjusted least squares means was computed and a significance level was set at $P \leq 0.10$. No weaning treatment $\times$ heifer development treatment was observed $P>0.10$ therefore, only main effects are presented.

Heifer performance data collected during the development period at JG were analyzed using the MIXED procedure in SAS (SAS Inst. Inc., Cary, NC) with a model that included weaning treatment (NW, EW-69, and EW57). Covariates used included ADG from birth to time of early weaning. Tukey-Kramer adjusted least squares means were used to compare differences between significant variables at $P \leq 0.05$.

Estrous response, AI conception rate, and pregnancy rate for the JG heifers was evaluated using PROC LOGISTIC (SAS Inst. Inc., Cary, NC) with a model that included weaning treatment (NW, EW-69, and EW-57). Tukey-Kramer adjusted least squares means were computed and a significance level was set at $P \leq 0.10$.

\section{Results}

\subsection{Early weaning}

\subsubsection{LARRL}

Average age of heifers at LARRL at time of early weaning were similar $(P=0.45$; Table 3$)$. Birth $\mathrm{BW}$ of heifer calves were also similar $(P=0.98)$ between weaning treatment. Daily gain of heifers from birth to early weaning were similar $(P=0.32)$ among weaning treatments. Initial BW at time of early weaning for heifer calves were similar for weaning treatment $(P=0.69)$. However, difference in ending BW were realized $(P=0.07)$ with EW heifers weighing greater than NW heifers $(P=0.02)$. This change in BW over the 133-d period from time of early weaning to normal weaning resulted in EW heifers gaining $14 \mathrm{~kg}$ more than NW heifers $(P=0.01)$.

Serum metabolite concentrations at time of early weaning were similar for LARRL heifers [glucose $(P=0.91)$, insulin $(P=0.49)$, NEFA $(P=0.53)$, and Urea N $(P=0.77)$; Table 4]. Serum glucose and NEFA concentrations were also similar after the $133-d$ period $(P=0.70$ and $P=0.18$, respectively). However, insulin concentrations were lesser for NW heifers compared to EW heifers $(P=0.04)$ and EW heifers receiving EW-69 had a tendency to have lower insulin concentrations than EW-57 heifers $(P=0.09)$. 
Table 3

Least squares means \pm SEM for production performance for heifers receiving weaning treatments over 133-d period at the Fort Keogh Livestock and Range Research Laboratory in 2005-2006.

\begin{tabular}{|c|c|c|c|c|c|c|c|}
\hline \multirow[b]{2}{*}{ Item $^{a}$} & \multicolumn{3}{|c|}{ Treatment $^{\mathrm{b}}$} & \multirow[b]{2}{*}{ SEM } & \multirow[b]{2}{*}{$P$-value } & \multicolumn{2}{|c|}{ Estimates $^{\mathrm{c}}$} \\
\hline & NW & EW-69 & EW-57 & & & 1 & 2 \\
\hline$n=$ & 109 & 109 & 110 & - & - & - & - \\
\hline Age at EW (d) & 83.7 & 83.9 & 81.1 & 7.72 & 0.45 & 0.57 & 0.26 \\
\hline \multicolumn{8}{|l|}{ Body weight (kg) } \\
\hline Birth (BW) & 34 & 34 & 34 & 0.44 & 0.98 & 0.88 & 0.87 \\
\hline ADG birth to EW $(\mathrm{kg} / \mathrm{d})$ & 0.97 & 0.98 & 1.01 & 0.02 & 0.32 & 0.21 & 0.40 \\
\hline Heifer BW at EW (kg) & 115 & 116 & 114 & 1.62 & 0.69 & 0.84 & 0.40 \\
\hline Heifer BW at NW (kg) & 224 & 239 & 238 & 5.13 & 0.07 & 0.02 & 0.82 \\
\hline Heifer BW change (kg) & 109 & 124 & 124 & 4.68 & 0.04 & 0.01 & 0.97 \\
\hline
\end{tabular}

${ }^{\text {a }}$ Early weaning (EW); body weight (BW); average daily gain (ADG); normal weaning (NW).

${ }^{\mathrm{b}}$ EW-69 (69\% ruminally degradable protein) and EW-57 (57\% ruminally degradable protein).

${ }^{c}$ Estimates: $1=\mathrm{NW}$ vs. EW-69+EW-57; $2=\mathrm{EW}-69$ vs. EW-57.

Table 4

Least squares means \pm SEM for serum metabolites for heifers receiving weaning treatments over 133-d period at the Fort Keogh Livestock and Range Research Laboratory in 2005-2006.

\begin{tabular}{|c|c|c|c|c|c|c|c|}
\hline \multirow[b]{2}{*}{ Item $^{\mathrm{a}}$} & \multicolumn{3}{|c|}{ Treatment $^{\mathrm{b}}$} & \multirow[b]{2}{*}{ SEM } & \multirow[b]{2}{*}{$P$-value } & \multicolumn{2}{|c|}{ Estimates $^{\mathrm{c}}$} \\
\hline & NW & EW-69 & EW-57 & & & 1 & 2 \\
\hline$n=$ & 109 & 109 & 110 & - & - & - & - \\
\hline \multicolumn{8}{|l|}{ Serum metabolites } \\
\hline Glucose (mg/100 mL) & 77.81 & 76.63 & 76.14 & 2.96 & 0.91 & 0.69 & 0.90 \\
\hline Insulin $(\mathrm{ng} / \mathrm{mL})$ & 0.24 & 0.28 & 0.25 & 0.02 & 0.49 & 0.35 & 0.46 \\
\hline NEFA $(\mu \mathrm{mol} / \mathrm{L})$ & 344 & 352 & 360 & 10.10 & 0.53 & 0.33 & 0.57 \\
\hline Urea $\mathrm{N}(\mathrm{mg} / 100 \mathrm{~mL})$ & 7.32 & 7.13 & 7.41 & 0.29 & 0.77 & 0.90 & 0.48 \\
\hline \multicolumn{8}{|l|}{ At normal weaning } \\
\hline Glucose $(\mathrm{mg} / 100 \mathrm{~mL})$ & 79.43 & 83.33 & 86.44 & 6.12 & 0.70 & 0.45 & 0.69 \\
\hline Insulin (ng/mL) & 0.25 & 0.36 & 0.57 & 0.09 & 0.03 & 0.04 & 0.09 \\
\hline $\mathrm{NEFA}(\mu \mathrm{mol} / \mathrm{L})$ & 342 & 232 & 309 & 45.29 & 0.18 & 0.18 & 0.19 \\
\hline Urea $\mathrm{N}(\mathrm{mg} / 100 \mathrm{~mL})$ & 5.89 & 14.05 & 13.87 & 0.48 & $<0.01$ & $<0.01$ & 0.77 \\
\hline \multicolumn{8}{|c|}{ Change normal-early weaning } \\
\hline Glucose $(\mathrm{mg} / 100 \mathrm{~mL})$ & 1.33 & 6.93 & 10.43 & 3.80 & 0.21 & 0.11 & 0.48 \\
\hline Insulin $(\mathrm{ng} / \mathrm{mL})$ & 0.01 & 0.09 & 0.31 & 0.09 & 0.06 & 0.09 & 0.09 \\
\hline NEFA $(\mu \mathrm{mol} / \mathrm{L})$ & 0.4 & -119 & -51 & 48.43 & 0.19 & 0.14 & 0.28 \\
\hline Urea $\mathrm{N}(\mathrm{mg} / 100 \mathrm{~mL})$ & -1.47 & 6.93 & 4.64 & 0.66 & $<0.01$ & $<0.01$ & 0.59 \\
\hline
\end{tabular}

\footnotetext{
${ }^{\text {a }}$ Non-esterified fatty acid (NEFA).

${ }^{\mathrm{b}}$ Treatments assigned at early weaning=normal weaning (NW); early weaning (EW); EW-69 (69\% ruminally degradable protein) and EW-57 (57\% ruminally degradable protein).

${ }^{\mathrm{c}}$ Estimates: $1=\mathrm{NW}$ vs EW-69+EW-57; 2=EW-69 vs. EW-57.
}

Similarly, urea N concentrations were lesser for NW heifers compared to EW heifers $(P<0.01)$ regardless of early weaning treatment. There was a tendency $(P=0.09)$ for serum insulin concentrations for NW increase lesser over the 133-d period (normal-early weaning) than both EW-69 and EW-57 and EW-69 to increased lesser than EW-57. However, changes in urea $\mathrm{N}$ concentrations decreased $(P<0.01)$ for NW heifers whereas EW-69 and EW-57 concentrations increased.

\subsubsection{JG}

Average age of heifers at JG at time of early weaning were similar $(P=0.79$; Table 5$)$. Birth BW of heifer calves were also similar $(P=0.72)$ for weaning treatment. Daily gain of heifers from birth to time of early weaning were $\operatorname{similar}(P=0.50)$ among heifer weaning treatments. Initial on test BW for heifer calves were similar for weaning treatment $(P=0.91)$. However, difference in ending BW was realized $(P=0.05)$ with NW heifers weighting lesser than EW heifers $(P=0.02)$. The change in BW over the 133-d period from time of early weaning to normal weaning resulted in EW heifers gaining $13 \mathrm{~kg}$ more than NW heifers $(P=0.02)$.

Serum metabolite concentrations at time of early weaning were similar for JG heifers [glucose $(P=0.35)$, insulin $(P=0.79)$, NEFA $(P=0.83)$, and urea $\mathrm{N}(P=0.58)$; Table 6$]$. Serum glucose and insulin concentrations were also similar after the $133-\mathrm{d}$ period $(P=0.33$ and $P=0.11$, respectively). However, NEFA concentrations were greater for EW-69 heifers compared to EW-57 heifers $(P<0.01)$. Concentrations for urea $\mathrm{N}$ were lesser for NW heifers compared to EW heifers $(P<0.01)$. Changes in serum NEFA concentrations for 
Table 5

Least squares means \pm SEM for production performance for heifers receiving weaning treatments over 133-d period at the Judith Gap location in 2005.

\begin{tabular}{|c|c|c|c|c|c|c|c|}
\hline \multirow[b]{2}{*}{ Item $^{a}$} & \multicolumn{3}{|c|}{ Treatment $^{\mathrm{b}}$} & \multirow[b]{2}{*}{ SEM } & \multirow[b]{2}{*}{$P$-value } & \multicolumn{2}{|c|}{ Estimates $^{\mathrm{c}}$} \\
\hline & NW & EW-69 & EW-57 & & & 1 & 2 \\
\hline$n=$ & 57 & 55 & 55 & - & - & - & - \\
\hline Age at EW (d) & 84.2 & 77.7 & 80.1 & 6.87 & 0.79 & 0.52 & 0.81 \\
\hline \multicolumn{8}{|l|}{ Body weight $(\mathrm{kg})$} \\
\hline Birth (BW) & 36 & 38 & 36 & 1.65 & 0.72 & 0.51 & 0.63 \\
\hline ADG birth to EW $(\mathrm{kg} / \mathrm{d})$ & 0.81 & 0.85 & 0.86 & 0.04 & 0.50 & 0.25 & 0.84 \\
\hline Heifer BW at EW (kg) & 105 & 103 & 104 & 3.36 & 0.91 & 0.78 & 0.74 \\
\hline Heifer BW at NW $(\mathrm{kg})$ & 269 & 280 & 283 & 4.27 & 0.05 & 0.02 & 0.63 \\
\hline Heifer BW change ( $\mathrm{kg})$ & 165 & 177 & 179 & 4.69 & 0.08 & 0.02 & 0.83 \\
\hline
\end{tabular}

${ }^{a}$ Early weaning (EW); body weight (BW); average daily gain (ADG); normal weaning (NW)

b Treatments assigned at early weaning=normal weaning (NW); early weaning (EW); EW-69 (69\% ruminally degradable protein) and EW-57 (57\% ruminally degradable protein).

${ }^{\mathrm{c}}$ Estimates: $1=\mathrm{NW}$ vs. EW-69+EW-57; $2=$ EW-69 vs. EW-57.

Table 6

Least squares means \pm SEM for serum metabolites for heifers receiving weaning treatments over 133-d period at the Judith Gap location in 2005.

\begin{tabular}{|c|c|c|c|c|c|c|c|}
\hline \multirow[b]{2}{*}{ Item $^{a}$} & \multicolumn{3}{|c|}{ Treatment $^{\mathrm{b}}$} & \multirow[b]{2}{*}{ SEM } & \multirow[b]{2}{*}{$P$ - value } & \multicolumn{2}{|c|}{ Estimates $^{c}$} \\
\hline & NW & EW-69 & EW-57 & & & 1 & 2 \\
\hline$n=$ & 57 & 55 & 55 & - & - & - & - \\
\hline \multicolumn{8}{|l|}{$\begin{array}{l}\text { Serum metabolites } \\
\text { At early weaning }\end{array}$} \\
\hline Glucose $(\mathrm{mg} / 100 \mathrm{~mL})$ & 80.58 & 77.02 & 77.97 & 1.79 & 0.35 & 0.16 & 0.71 \\
\hline Insulin $(\mathrm{ng} / \mathrm{mL})$ & 0.17 & 0.18 & 0.16 & 0.02 & 0.79 & 0.90 & 0.49 \\
\hline NEFA (цmol/L) & 358 & 371 & 343 & 32.50 & 0.83 & 0.98 & 0.54 \\
\hline Urea $\mathrm{N}(\mathrm{mg} / 100 \mathrm{~mL})$ & 7.7 & 7.9 & 8.2 & 0.37 & 0.58 & 0.41 & 0.52 \\
\hline \multicolumn{8}{|l|}{ At normal weaning } \\
\hline Glucose $(\mathrm{mg} / 100 \mathrm{~mL})$ & 67.00 & 65.06 & 68.19 & 1.52 & 0.33 & 0.84 & 0.14 \\
\hline Insulin (ng/mL) & 0.31 & 0.32 & 0.22 & 0.04 & 0.11 & 0.35 & 0.06 \\
\hline NEFA (цmol/L) & 315 & 492 & 263 & 43.97 & $<0.01$ & 0.25 & $<0.01$ \\
\hline Urea $\mathrm{N}(\mathrm{mg} / 100 \mathrm{~mL})$ & 8.59 & 17.75 & 17.80 & 0.79 & $<0.01$ & $<0.01$ & 0.96 \\
\hline \multicolumn{8}{|l|}{$\begin{array}{l}\text { Change } \\
\text { Normal-early weaning }\end{array}$} \\
\hline Glucose $(\mathrm{mg} / 100 \mathrm{~mL})$ & -13.43 & -12.31 & -9.52 & 2.30 & 0.47 & 0.38 & 0.39 \\
\hline Insulin $(\mathrm{ng} / \mathrm{mL})$ & 0.14 & 0.13 & 0.06 & 0.05 & 0.40 & 0.43 & 0.27 \\
\hline NEFA (цmol/L) & -40 & 121 & -80 & 32.53 & $<0.01$ & 0.13 & $<0.01$ \\
\hline Urea $\mathrm{N}(\mathrm{mg} / 100 \mathrm{~mL})$ & 1.07 & 9.81 & 9.46 & 1.09 & $<0.01$ & $<0.01$ & 0.82 \\
\hline
\end{tabular}

\footnotetext{
a Non-esterified fatty acid (NEFA).

b Treatments assigned at early weaning=normal weaning (NW); early weaning (EW); EW-69 (69\% ruminally degradable protein) and EW-57 (57\% ruminally degradable protein).

${ }^{\mathrm{c}}$ Estimates: $1=\mathrm{NW}$ vs. EW-69+EW-57; 2=EW-69 vs. EW-57.
}

EW-69 increased whereas EW-57 heifers decreased over the 133-d period $(P<0.01)$. Changes in urea $\mathrm{N}$ concentrations increased lesser $(P<0.01)$ for NW heifers than either EW-69 and EW-57 heifers.

\subsection{Heifer development}

\subsubsection{Experiment 1}

Heifers had similar BW at the inception and termination of the heifer development period $(P=0.73$ and $P=0.79$, respectively) regardless of heifer development treatment and had similar BW changes throughout the developmental period ( $P=0.92$; Table 7$)$. However, heifers that received early weaning treatments started and ended the heifer development period weighing more $(P<0.01)$ and NW heifers gained more BW throughout the development period $(P<0.01)$ compared to heifers that were early weaned.

Serum metabolites measured at the initiation of heifer development were similar for glucose $(P=0.94)$, insulin $(P=0.92)$, NEFA $(P=0.57)$, and urea $\mathrm{N}(P=0.32)$ regardless of heifer development treatment (Table 7$)$. Differences in serum metabolites were measured depending on early weaning treatment. Heifers that received the NW treatment had lesser concentrations of serum glucose $(P<0.01)$, insulin $(P<0.01)$, and urea $\mathrm{N}(P<0.01)$ while serum NEFA 
Table 7

Least squares means \pm SEM for production performance and serum metabolites based on weaning and heifer development treatments in 2005-2006 (Exp. 1).

\begin{tabular}{|c|c|c|c|c|c|c|c|c|c|c|}
\hline \multirow[b]{2}{*}{ Item $^{a}$} & \multicolumn{3}{|c|}{ Weaning treatment ${ }^{\mathrm{b}}$} & \multirow[b]{2}{*}{ SEM } & \multirow[b]{2}{*}{$P$-value } & \multirow[b]{2}{*}{ Effect $^{d}$} & \multicolumn{2}{|c|}{ Development treatment ${ }^{\mathrm{c}}$} & \multirow[b]{2}{*}{ SEM } & \multirow[b]{2}{*}{$P$-value } \\
\hline & NW & EW-69 & EW-57 & & & & HD-83 & HD-72 & & \\
\hline$n=$ & 106 & 109 & 109 & & & & 162 & 162 & & \\
\hline \multicolumn{11}{|l|}{ Body weight (kg) } \\
\hline At start of HD & 235 & 264 & 263 & 3.14 & $<0.01$ & $<0.01$ & 253.0 & 254.4 & 2.82 & 0.73 \\
\hline At end of HD & 317 & 339 & 338 & 5.68 & $<0.01$ & $<0.01$ & 330.0 & 332.6 & 7.00 & 0.79 \\
\hline Body weight change & 83 & 75 & 74 & 6.46 & $<0.01$ & $<0.01$ & 77.0 & 78.2 & 9.00 & 0.92 \\
\hline \multicolumn{11}{|l|}{ On test serum metabolites } \\
\hline Glucose (mg/100 mL) & 78.5 & 83.5 & 86.4 & 3.67 & $<0.01$ & $<0.01$ & 83.1 & 82.5 & 4.94 & 0.94 \\
\hline Insulin (ng/mL) & 0.26 & 0.36 & 0.42 & 0.03 & $<0.01$ & $<0.01$ & 0.34 & 0.35 & 0.03 & 0.92 \\
\hline NEFA (цmol/L) & 355 & 234 & 310 & 23.12 & $<0.01$ & $<0.01$ & 287.0 & 311.4 & 30.35 & 0.57 \\
\hline Urea $\mathrm{N}(\mathrm{mg} / 100 \mathrm{~mL})$ & 6.06 & 14.10 & 13.89 & 0.29 & $<0.01$ & $<0.01$ & 11.56 & 11.14 & 0.30 & 0.32 \\
\hline \multicolumn{11}{|l|}{ Off test serum metabolites } \\
\hline Glucose (mg/100 mL) & 77.02 & 76.80 & 78.32 & 0.81 & 0.18 & - & 77.19 & 77.57 & 0.88 & 0.76 \\
\hline Insulin (ng/mL) & 0.36 & 0.37 & 0.39 & 0.02 & 0.44 & - & 0.34 & 0.41 & 0.02 & 0.03 \\
\hline NEFA (цmol/L) & 432 & 447 & 415 & 20.43 & 0.36 & - & 434.4 & 427.8 & 22.21 & 0.83 \\
\hline Urea N (mg/100 mL) & 6.94 & 6.85 & 6.91 & 0.40 & 0.79 & - & 6.39 & 7.41 & 0.55 & 0.19 \\
\hline \multicolumn{11}{|l|}{ Change in serum metabolites } \\
\hline Glucose change $(\mathrm{mg} / 100 \mathrm{~mL})$ & -1.35 & -6.81 & -8.38 & 3.15 & $<0.01$ & $<0.01$ & -5.96 & -5.07 & 4.12 & 0.88 \\
\hline Insulin change $(\mathrm{ng} / \mathrm{mL})$ & 0.11 & 0.01 & -0.03 & 0.04 & 0.01 & $<0.01$ & -0.0001 & 0.07 & 0.03 & 0.17 \\
\hline NEFA change ${ }^{\mathrm{e}}$ (цmol/L) & 76 & 212 & 107 & 30.40 & $<0.01$ & $<0.01$ & 147.5 & 115.6 & 37.27 & 0.55 \\
\hline Urea $\mathrm{N}$ change $(\mathrm{mg} / 100 \mathrm{~mL})$ & 0.92 & -7.30 & -6.99 & 0.37 & $<0.01$ & $<0.01$ & -5.18 & -3.74 & 0.52 & 0.02 \\
\hline
\end{tabular}

a Non-esterified fatty acid (NEFA).

b Treatments assigned at normal weaning (NW); early weaning (EW); EW-69 (69\% ruminally degradable protein) and EW-57 (57\% ruminally degradable protein).

c Treatment=heifer development (HD); HD-83 (83\% ruminally degradable protein) and HD-72 (72\% ruminally degradable protein).

d Significant estimates for treatment; NW vs. EW-69+EW-57.

e Significant estimates for treatment $(P<0.01)$; EW-69 vs. EW-57.

concentrations were greater $(P<0.01)$ for NW heifers. At termination of the heifer development period serum metabolite concentrations were similar for weaning treatments $(P>0.10)$ and heifer development treatment did not influence serum concentrations of glucose $(P=0.76)$, NEFA $(P=0.83)$, or urea $\mathrm{N}(P=0.19)$. However, heifers receiving HD-72 which contained a lesser percentage of RDP had greater serum insulin concentrations $(P=0.03)$ at the termination of the heifer development period compared to HD-83 heifers. Changes in serum metabolites measured throughout the heifer development period were similar for serum glucose $(P=0.88)$, insulin $(P=0.17)$, and NEFA $(P=0.55)$ regardless of heifer development treatment. With the exception of serum urea $\mathrm{N}$ which decreased lesser for heifers receiving $\mathrm{HD}-72(P=0.02)$ compared to $\mathrm{HD}-83$ heifers. Heifers that had previously received EW-69 and EW-57 during the early weaning phase had substantially lower concentrations of serum glucose $(P<0.01)$ and urea $\mathrm{N}(P<0.01)$ compared to NW heifers. Serum insulin was greater in heifers that received NW treatment compared to heifers that received the EW treatment $(P=0.01)$, and serum NEFA concentration were greater in EW heifers compared to heifers that were NW $(P<0.01)$ with EW-69 heifers having greater serum NEFA concentrations than EW-57 heifers $(P<0.01)$.

Heifers were assessed for pubertal status beginning $50 \mathrm{~d}$ before the start of breeding. On d 50 before breeding serum progesterone measurements were similar for both weaning treatment and heifer development treatment
( $P>0.40$; Table 8). However, from d 39 to d 2 before breeding heifers that had received EW treatments had a greater percentage of pubertal heifers than NW heifers $(P<0.06)$. Dominant ovulatory follicle measured approximately $12 \mathrm{~h}$ following the onset of estrus was not influenced by weaning treatment $(P=0.93)$ or heifer development treatment $(P=0.82)$. Estrous response to $\mathrm{AI}, \mathrm{AI}$ conception rate, AI pregnancy rate, and breeding season pregnancy rate were not affected by weaning or heifer development treatments $(P>0.10)$.

\subsubsection{Experiment 2}

Early weaning treatments had no influence on initial BW $(P=0.18)$, final BW $(P=0.35)$, or BW change $(P=0.48)$ during the heifer development period (Table 9$)$. Estrous response to $\mathrm{AI}(P=0.30)$, AI conception rate $(P=0.14)$, and AI pregnancy rates $(P=0.25)$ were not influenced by experimental treatments. Conception rate of EW-69 heifers tended to be greater $(P=0.09)$ than conception rate of EW57 heifers. Final breeding season pregnancy rates were greater $(P=0.03)$ for EW compared to NW treated heifers and greater $(P<0.01)$ for EW-69 then EW-57 heifers.

\section{Discussion}

\subsection{Early weaning}

Average daily gain from birth to time of early weaning was similar for heifers within each study location (LARRL 
Table 8

Least squares means \pm SEM for reproduction performance based on weaning and heifer development treatments in 2005-2006 (Exp. 1).

\begin{tabular}{|c|c|c|c|c|c|c|c|c|c|c|}
\hline \multirow[b]{2}{*}{ Item } & \multicolumn{3}{|c|}{ Weaning treatment ${ }^{\mathrm{a}}$} & \multirow[b]{2}{*}{ SEM } & \multirow[b]{2}{*}{$P$-value } & \multirow[b]{2}{*}{ Effect $^{\mathrm{c}}$} & \multicolumn{2}{|c|}{ Development treatment $^{\mathrm{b}}$} & \multirow[b]{2}{*}{ SEM } & \multirow[b]{2}{*}{$P$-value } \\
\hline & NW & EW-69 & EW-57 & & & & HD-83 & HD-72 & & \\
\hline$n=$ & 106 & 109 & 109 & & & & 162 & 162 & & \\
\hline \multicolumn{11}{|l|}{ Pubertal prior to start of breeding (\%) } \\
\hline Day 50 & 63.2 & 71.6 & 68.8 & - & 0.41 & - & 69.8 & 66.1 & - & 0.48 \\
\hline Day 39 & 76.4 & 90.8 & 83.5 & - & 0.02 & 0.01 & 82.1 & 85.2 & - & 0.45 \\
\hline Day 29 & 79.3 & 93.6 & 89.0 & - & 0.01 & $<0.01$ & 87.7 & 87.0 & - & 0.87 \\
\hline Day 22 & 83.0 & 95.4 & 90.8 & - & 0.01 & $<0.01$ & 90.1 & 89.5 & - & 0.85 \\
\hline Day 11 & 87.7 & 96.3 & 95.4 & - & 0.02 & $<0.01$ & 93.8 & 92.6 & - & 0.66 \\
\hline Day 2 & 92.5 & 97.3 & 96.3 & - & 0.02 & 0.06 & 96.9 & 93.8 & - & 0.19 \\
\hline \multicolumn{11}{|l|}{ Reproduction } \\
\hline Ovulatory follicle size $(\mathrm{mm})$ & 12.2 & 12.3 & 12.6 & 0.28 & 0.93 & - & 12.4 & 12.3 & 0.33 & 0.82 \\
\hline AI estrous response ${ }^{d}(\%)$ & 87.7 & 86.2 & 91.7 & - & 0.42 & - & 88.3 & 88.9 & - & 0.86 \\
\hline AI conception rate ${ }^{\mathrm{e}}(\%)$ & 75.3 & 68.1 & 66.0 & - & 0.34 & - & 66.4 & 72.9 & - & 0.23 \\
\hline AI pregnancy rate ${ }^{\mathrm{f}}(\%)$ & 66.0 & 58.7 & 60.6 & - & 0.52 & - & 58.6 & 64.8 & - & 0.25 \\
\hline Breeding season pregnancy rate (\%) & 90.6 & 90.8 & 92.7 & - & 0.84 & - & 90.1 & 92.6 & - & 0.43 \\
\hline
\end{tabular}

a Treatments assigned at normal weaning (NW); early weaning (EW); EW-69 (69\% ruminally degradable protein) and EW-57 (57\% ruminally degradable protein).

b Treatment = heifer development (HD); HD-83 (83\% ruminally degradable protein) and HD-72 (72\% ruminally degradable protein).

c Significant estimates for treatment; NW vs. EW-69+EW-57.

${ }^{\mathrm{d}}$ Artificial insemination (AI) estrous response was defined as percentage of heifers detected in estrus and artificially inseminated during an 11-d AI period.

e $\mathrm{AI}$ conception rate $=\#$ of pregnant from $\mathrm{AI} / \#$ of heifers receiving $\mathrm{AI}$.

${ }^{\mathrm{f}} \mathrm{AI}$ pregnancy rate $=\#$ of heifers from $\mathrm{AI} /$ total \# of heifers in treatment group.

Table 9

Least squares means \pm SEM for heifer production and reproductive performance during heifer development (HD) based on weaning treatments in 2005 (Exp. 2).

\begin{tabular}{|c|c|c|c|c|c|c|}
\hline \multirow[b]{2}{*}{ Item } & \multicolumn{3}{|c|}{ Weaning treatment ${ }^{\mathrm{a}}$} & \multirow[b]{2}{*}{ SEM } & \multirow[b]{2}{*}{$P$-value } & \multirow[b]{2}{*}{ Effect $^{\mathrm{b}}$} \\
\hline & NW & EW-69 & EW-57 & & & \\
\hline$n=$ & 44 & 43 & 47 & - & - & \\
\hline \multicolumn{7}{|l|}{ Body weight (BW) $(\mathbf{k g})$} \\
\hline Heifer BW at start of HD (kg) & 322 & 313 & 323 & 4.27 & 0.18 & - \\
\hline Heifer BW at termination of $\mathrm{HD}(\mathrm{kg})$ & 372 & 362 & 366 & 5.27 & 0.35 & - \\
\hline Heifer BW change $(\mathrm{kg})$ & 49 & 49 & 44 & 3.63 & 0.48 & - \\
\hline \multicolumn{7}{|l|}{ Reproduction } \\
\hline AI estrous response ${ }^{\mathrm{c}}(\%)$ & 72.7 & 86.1 & 76.6 & - & 0.30 & - \\
\hline AI conception rate ${ }^{\mathrm{d}}(\%)$ & 59.4 & 75.0 & 52.8 & - & 0.14 & 0.09 \\
\hline AI pregnancy rate ${ }^{\mathrm{e}}(\%)$ & 45.5 & 60.5 & 44.7 & - & 0.25 & - \\
\hline Breeding season pregnancy rate (\%) & 60.5 & 86.1 & 68.1 & - & 0.03 & $<0.01$ \\
\hline
\end{tabular}

a Treatments assigned at early weaning=normal weaning (NW); early weaning (EW); EW-69 (69\% ruminally degradable protein) and EW-57 (57\% ruminally degradable protein).

b Significant estimates for treatment; EW-69 vs. EW-57.

${ }^{c}$ Artificial insemination (AI) estrous response was defined as percentage of heifers detected in estrus and artificially inseminated during an 11-d AI period.

${ }^{\mathrm{d}} \mathrm{AI}$ conception rate $=\#$ of pregnant from $\mathrm{AI} /$ \# of heifers receiving $\mathrm{AI}$.

e $\mathrm{AI}$ pregnancy rate $=\#$ of heifers from $\mathrm{AI} /$ total \# of heifers in treatment group.

and JG, respectively). This research suggests that ADG from birth to weaning may be influenced by season of birth where heifers calves born in late winter and dams are not able to graze green forage during the early postpartum have restricted calf gains compared to heifer calves born in early spring when there is a greater opportunity for their dam to consume succulent green vegetation. Studies have documented the importance of dam milk yield on subsequent calf gain (Neville, 1962; Robison et al., 1978; Rutledge et al., 1971). Heifer calves from both studies responded similarly to early weaning treatments. Heifers that were early weaned and received diets higher in TDN and CP (regardless of protein source) gained more weight than their cohorts that remained on their dams throughout the 133-d period leading up to time of normal weaning. Body weight measurements agree with previous reports that early weaned calves weighed more than calves weaned at the time of normal weaning (Barker-Neef et al., 2001; Blanco et al., 2009; Myers et al., 1999; Neville and McCormick, 1981). Differences in heifers BW at normal weaning may also be influenced by interannual changes in vegetation quality 
due to environmental conditions (Waterman et al., 2007; Waterman et al., in press). This helps to explain differences in BW at normal weaning when more than one geographical location is evaluated. Lusby et al. (1981) observed similar gains between normal weaned calves and early weaned calves that were not exposed to seasonal diet quality changes or with use of harvested feeds in confinement. They also observed a $20 \mathrm{~kg}$ reduction in BW at time of normal weaning (i.e., 7 months) for early weaned calves grown on pasture with creep-feed rather than fed harvested feeds in confinement. These authors concluded that weaning onto pasture with supplemental creep feed requires that pastures be of high quality if performance is to be equal to that of a complete confinement ration. Early weaning diets in the present study were formulated to provide equal amounts of $\mathrm{CP}$, but differ slightly in site of protein digestion (rumen vs. abomasum). Form of supplemental protein did not influence BW measurements suggesting that metabolizable protein reaching the small intestine was sufficient in each of the early weaning diets.

Serum metabolites at early and normal weaning were evaluated to help explain potential differences in basal metabolic status and if weaning treatments may cause any subsequent fertility differences during subsequent heifer development. Serum metabolite results showed similarities between heifer calves at time of early weaning. Differences in serum metabolites were measured at the end of the 133-d period at time of normal weaning. Heifers at LARRL that received EW-69 and EW-57 both had elevated serum insulin concentrations with EW-57 heifers, or heifers receiving the greater quantity of rumen undegradable protein, having the greatest concentration. Hunter and Magner (1988) report that diets greater in rumen undegradable protein may stimulate insulin secretion due to continual flow of protein for absorption in the small intestine. These results also agree with previous studies where ruminal undegradable protein was offered (Lalman et al., 1993; Sletmoen-Olson et al., 2000; Waterman et al., 2006; Wiley et al., 1991). However, the response to insulin was not observed for heifers at the JG location. Kane et al. (2004) reports that insulin response to rumen undegradable protein may be influenced by environment and duration that rumen undegradable protein is offered. In addition, the responses of serum NEFA concentrations at the end of the 133-d period ending at normal weaning differed between heifers at LARRL and JG. Serum NEFA concentrations were similar for heifers at LARRL whereas; heifers at JG that received EW-69 had greater NEFA concentrations than EW-57 heifers. These differences in NEFA concentrations most likely are contributed to environment and potentially genetic differences between these herds. Despite the aforementioned dissimilarities heifers at both locations that received the early weaning treatments had greater urea $\mathrm{N}$ concentrations than their normal weaned cohorts.

\subsection{Heifer development}

Development of heifers to calve by 24 months of age not only necessitates that proper BW must be achieved but the reproductive process must also be active by no later than 15 months of age. In experiment 1 , studies conducted at LARRL evaluated the development of heifers that received weaning treatments (NW, EW-69 or EW-57) and subsequently assigned heifer development treatments (HD-83 and HD-72) on BW, serum metabolites and reproductive performance.

Heifer BW during the heifer development period was not influenced by type of protein delivered in experimental diets but was consistently reflective of early weaning treatments with heifers that were early weaning continually being heavier at LARRL. However, heifers that received the normal weaning treatment at LARRL did gain more BW throughout the heifer development period but still came short of obtaining equal weights to cohorts that received the early weaning treatment. Body weights for JG heifers were similar regardless of weaning treatment.

Serum progesterone concentrations were used to evaluate the number of heifers that had obtained puberty before the start of breeding and prior to $\mathrm{PGF}_{2 \alpha}$ administration of the breeding synchronization protocol. Heifers that received EW weaning treatments consistently had a greater number of heifers pubertal beginning $39 \mathrm{~d}$ prior to the start of breeding. However, AI pregnancy rates were similar regardless of weaning or heifer development treatment at LARRL. Overall breeding season rates were also similar at LARRL for heifers that were early weaned. Roberts et al. (2009) reported that heifers with greater average daily gain from birth to 8 months of age had improved AI pregnancy rates. Results from the present study found similar ADG from birth to time of early weaning (2.5 months of age) for heifers at LARRL and JG. Although we observed a greater percentage of heifers that achieved puberty prior to AI in EW treated heifers, an improvement in AI pregnancy rates was not realized. However, heifers at JG that had received the early weaning treatment had a greater percentage pregnant at the end of the breeding season compared to normal weaned heifers.

In conclusion, changes were observed for BW and serum metabolites for early weaning and heifer development portions of this study. Heifer BW at normal weaning was improved using early weaning strategies without any detrimental effect on reproductive measures for heifers. This study demonstrates that both early and normal weaned heifers can be developed and bred in extensive beef production systems in the Northern Great Plains with similar outcomes. This data agrees with that of Clanton et al. (1983) and Grings et al. (2007), but disagrees with that of Roberts et al. (2009) in that timing of BW gain had no effect on reproductive performance. Therefore, weaning heifer calves early in times when forage availability is limiting or conditions when young cows are overstressed due to lactation, climatic or nutritional circumstances will not negatively impact the opportunity to retain replacement females.

\section{Conflict of interest}

Research was funded by the United States Department of Agriculture, Agricultural Research Service (Project 
\#5434-31000-014-00D). The authors declare there are no conflicts of interest.

\section{Acknowledgments}

The authors gratefully acknowledge W. Kelly, R.P. Ansotegui, C. Molle, M. Woods, and S. Bellows for their technical assistance and Dean and Trudi Petersen (Judith Gap, MT, 59453, USA) for providing cattle for use in this study. The authors also wish to acknowledge Teva Animal Health, St Joseph, MO 64503 for their support of this project. The authors would also like to express their gratitude to the Montana Beef Network for partial funding (early weaning feed for Judith Gap, MT, 59453, USA) of this project.

\section{References}

Arije, G.F., Wiltbank, J.N., 1971. Age and weight at puberty in Hereford heifers. J. Anim. Sci. 33, 401-406.

Barker-Neef, J.M., Buskirk, D.D., Blackt, J.R., Doumit, M.E., Rust, S.R., 2001. Biological and economic performance of early-weaned Angus steers. J. Anim. Sci. 79, 2762-2769.

Bellows, R.A., Staigmiller, R.B., Wilson, J.M., Phelps, D.A., Darling, A., 1991. Use of bovine FSH for superovulation and embryo production in beef heifers. Theriogenology 35, 1069-1082.

Blanco, M., Villalba, D., Ripoll, G., Sauerwein, H., Casasús, I., 2009. Effects of early weaning and breed on calf performance and carcass and meat quality in autumn-born bull calves. Livest. Sci. 120, 103-115.

Clanton, D.C., Jones, L.E., England, M.E., 1983. Effect of rate and time of gain after weaning on the development of replacement beef heifers. J. Anim. Sci. 56, 280-285.

Grings, E.E., Geary, T.W., Short, R.E., MacNeil, M.D., 2007. Beef heifer development within three calving systems. J. Anim. Sci. 85, 2048-2058.

Grings, E.E., Hall, J.B., Bellows, R.A., Short, R.E., Bellows, S.E., Staigmiller, R.B., 1998. Effect of nutritional management, trace mineral supplementation, and norgestomet implant on attainment of puberty in beef heifers. J. Anim. Sci. 76, 2177-2181.

Hunter, R.A., Magner, T., 1988. The effect of supplements of formaldehyde-treated casein on the partitioning of nutrients between cow and calf in lactating Bos indicus $\times$ Bos taurus heifers fed a roughage diet. Aust. J. Agric. Res. 39, 1151-1162.

Kane, K.K., Hawkins, D.E., Pulsipher, G.D., Denniston, D.J., Krehbiel, C.R., Thomas, M.G., Petersen, M.K., Hallford, D.M., Remmenga, M.D., Roberts, A.J., Keisler, D.H., 2004. Effect of increasing levels of undegradable intake protein on metabolic and endocrine factors in estrous cycling beef heifers(1,2). J. Anim. Sci. 82, 283-291.

Lalman, D.L., Petersen, M.K., Ansotegui, R.P., Tess, M.W., Clark, C.K., Wiley, J.S., 1993. The effects of ruminally undegradable protein, propionic acid, and monensin on puberty and pregnancy in beef heifers. J. Anim. Sci. 71, 2843-2852.
Lusby, K.S., Wettemann, R.P., Turman, T.E., 1981. Effects of early weaning calves from first-calf heifers on calf and heifer performance. J. Anim. Sci. 53, 1193-1197.

Myers, S.E., Faulkner, D.B., Ireland, F.A., Berger, L.L., Parrett, D.F., 1999. Production systems comparing early weaning to normal weaning with or without creep feeding for beef steers. J. Anim. Sci. 77, 300-310.

Neville Jr., W.E., McCormick, W.C., 1981. Performance of early- and normal-weaned beef calves and their dams. J. Anim. Sci. 52, 715-724.

Neville, W.E.J., 1962. Influence of dam's milk production and other factors on 120 adn 240-day weight of Hereford claves. J. Anim. Sci. 21, 315-320.

Perry, G.A., Smith, M.F., Roberts, A.J., MacNeil, M.D., Geary, T.W., 2007. Relationship between size of the ovulatory follicle and pregnancy success in beef heifers. J. Anim. Sci. 85, 684-689.

Pinney, D.O., Stephens, D.F., Pope, L.S., 1972. Lifetime effects of winter supplemental feed level and age at first parturition on range beef cows. J. Anim. Sci. 34, 1067-1074.

Roberts, A.J., Geary, T.W., Grings, E.E., Waterman, R.C., MacNeil, M.D., 2009. Reproductive performance of heifers offered ad libitum or restricted access to feed for a 140-d period after weaning. J. Anim. Sci. 87, 3043-3052.

Robison, O.W., Yusuff, M.K.M., Dillard, E.U., 1978. Milk production in Hereford cows: I. means and correlations. J. Anim. Sci. 47, 131-136.

Rutledge, J.J., Robison, O.W., Ahlschwede, W.T., Legates, J.E., 1971. Milk yield and its influence on 205-day weight of beef calves. J. Anim. Sci. 33, 563-567.

Short, R.E., Bellows, R.A., 1971. Relationships among weight gains, age at puberty and reproductive performance in heifers. J. Anim. Sci. 32, 127-131.

Sletmoen-Olson, K.E., Caton, J.S., Olson, K.C., Redmer, D.A., Kirsch, J.D. Reynolds, L.P., 2000. Undegraded intake protein supplementation: II. Effects on plasma hormone and metabolite concentrations in periparturient beef cows fed low-quality hay during gestation and lactation. J. Anim. Sci. 78, 456-463.

Swanson, E.W., 1960. Effect of rapid growth with fattening of dairy heifers on their lactational ability. J. Dairy Sci. 43, 377-387.

Waterman, R.C., Geary, T.W., Paterson, J.A., Lipsey, R.J. Early weaning in Northern Great Plains beef cattle production systems: I. Performance and reproductive response in range beef cows. Livest. Sci., <http:// dx.doi.org/10.1016/ j.livsci.2012.05.004 >, in press.

Waterman, R.C., Grings, E.E., Geary, T.W., Roberts, A.J., Alexander, L.J., MacNeil, M.D., 2007. Influence of seasonal forage quality on glucose kinetics of young beef cows. J. Anim. Sci. 85, 2582-2595.

Waterman, R.C., Sawyer, J.E., Mathis, C.P., Hawkins, D.E., Donart, G.B., Petersen, M.K., 2006. Effects of supplements that contain increasing amounts of metabolizable protein with or without Ca-propionate salt on postpartum interval and nutrient partitioning in young beef cows. J. Anim. Sci. 84, 433-446.

Wiley, J.S., Petersen, M.K., Ansotegui, R.P., Bellows, R.A., 1991. Production from first-calf beef heifers fed a maintenance or low level of prepartum nutrition and ruminally undegradable or degradable protein postpartum. J. Anim. Sci. 69, 4279-4293.

Wiltbank, J.N., Gregory, K.E., Swinger, L.A., Ingalls, J.E., Rothlisberger, J.A., Koch, R.M., 1966. Effects of heterosis on age and weight at puberty in beef heifers. J. Anim. Sci. 25, 744-751. 